\title{
POTENTIAL FOR A LOW-TEMPERATURE GEOTHERMAL RESOURCE NEAR MACKAY, DAHO
}

\author{
Prepared for \\ US. DEPARTMENT of ENERGY \\ DAHO OPERATIONS OFFICE \\ DAHO FALIS, DAHO \\ By \\ EARTH SCIENCE LABORATORY \\ UNIVERSITY OF UTAH RESEARCH INSTITUTE \\ SALT LARE CITY, UTAH
}

\section{Earth Science Laboratory}

\author{
University of Utah Research Institute \\ 391 Chipeta Way, Suite C \\ Salt Lake City, Utah 84108 \\ (801) 524-3422
}

OCTOBER, 1984 


\section{DISCLAIMER}

This report was prepared as an account of work sponsored by an agency of the United States Government. Neither the United States Government nor any agency Thereof, nor any of their employees, makes any warranty, express or implied, or assumes any legal liability or responsibility for the accuracy, completeness, or usefulness of any information, apparatus, product, or process disclosed, or represents that its use would not infringe privately owned rights. Reference herein to any specific commercial product, process, or service by trade name, trademark, manufacturer, or otherwise does not necessarily constitute or imply its endorsement, recommendation, or favoring by the United States Government or any agency thereof. The views and opinions of authors expressed herein do not necessarily state or reflect those of the United States Government or any agency thereof. 


\section{DISCLAIMER}

Portions of this document may be illegible in electronic image products. Images are produced from the best available original document. 
POTENTIAL FOR A LOW-TEMPERATURE GEOTHERMAL RESOURCE NEAR MACKAY, IDAHO

\section{by}

Bruce S. Sibbett and

Regina M. Capuano

Earth Science Laboratory University of Utah Research Institute Salt Lake City, Utah

\section{Prepared for}

U.S. Department of Energy Idaho Operations office Idaho Falls, Idaho

Under Contract No. DE-AC07-80ID12079 


\section{NOTICE}

This report was prepared to document work sponsored by the United States Government. Neither the United States nor its agent, the United States Department of Energy, nor any Federal employees, nor any of their contractors, subcontractors or their employees, makes any warranty, express or implied, or assumes any legal liability or responsibility for the accuracy, completeness, or usefulness of any information, apparatus, product or process disclosed, or represents that its use would not infringe privately owned rights.

\section{NOTICE}

Reference to a company or product name does not imply approval or recommendation of the product by the University of Utah Research Institute or the U.S. Department of Energy to the exclusion of others that may be suitable. 
TABLE OF CONTENTS

Page

ABSTRACT $\ldots \ldots \ldots \ldots \ldots \ldots \ldots \ldots \ldots \ldots \ldots \ldots \ldots \ldots \ldots \ldots \ldots \ldots \ldots \ldots \ldots \ldots \ldots \ldots \ldots \ldots \ldots$

INTRODUCTION....................................................

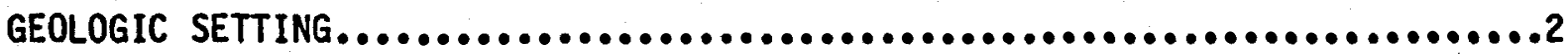

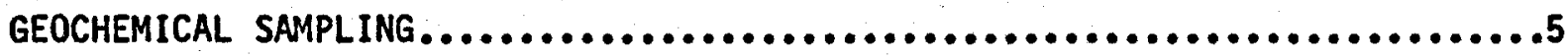

ANALYTIC RESULTS AND INTERPRETATION OF GEOTHERMOMETRY..................7

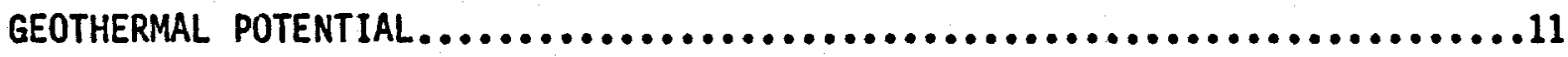

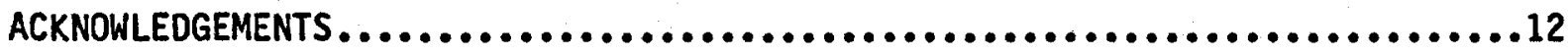

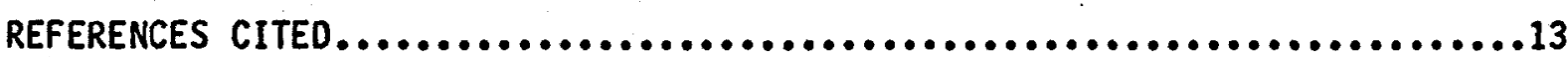

\section{FIGURES}

Figure 1. Sample Locations $\ldots \ldots \ldots \ldots \ldots \ldots \ldots \ldots \ldots \ldots \ldots \ldots \ldots \ldots \ldots \ldots \ldots \ldots \ldots \ldots \ldots$

Figure 2. Piper Plot of Water Samples from the Mackay Area...............8

TABLE

Table 1. Chemistry of Spring Waters..............................9 
ABSTRACT

Four water samples were collected from springs in the Mackay, Idaho area to investigate the potential for a direct-heat geothermal resource. The maximum measured temperature was $22^{\circ} \mathrm{C}$ for a spring south of Mackay. Calculation of the mineral equilibrium relationships in the calcium-bicarbonate water samples indicates that these samples equilibrated with the carbonate reservoir rocks. The temperatures of equilibration suggest that the subsurface temperatures of these water samples are probably no higher than measured surface temperatures.

1 


\section{INTRODUCTION}

Mackay, Idaho is located in the Big Lost River Valley, $34 \mathrm{~km}$ (21 miles) northwest of Arco, Idaho. The town of Mackay draws its water supply from City Spring, which produces a large volume of $18^{\circ} \mathrm{C}\left(64^{\circ} \mathrm{F}\right)$ water from the head of a small draw, $1.6 \mathrm{~km}$ ( $1 \mathrm{mile})$ southwest of town. The high school was damaged during the 1983 Challis earthquake and geothermal heating is being considered for a new high school being built. This report summarizes the results of a preliminary investigation of the geothermal potential of the Mackay area.

A brief visit was made to the area on April 11 and 12, 1984, to collect water samples and identify geologic structures that may be controlling springs and thermal fluid flow. Water samples were collected from four springs for geochemical analysis. Surface temperatures were measured at these four springs and at two other springs which were not sampled.

\section{GEOLOGIC SETTING}

Mackay, Idaho is located in a northwest-trending valley bounded at least on the north by normal faults (Fig. 1). Faulting on the north side of the valley has been active during the Quaternary, resulting in the Lost River Range having considerably higher relief than the White Knob Mountains to the south of the valley, and in a more sharply defined range front at the foot of the Lost River Range.

The. White Knob Mountains are primarily a limestone and granite horst bounded by northeast-trending faults. Rocks of the Challis Volcanics are also found in the White Knob Mountains (Fig. 1). The White Knob mining district, 5 $\mathrm{km}$ ( 3 miles) southwest of Mackay, produced copper and associated minerals from deposits in a Tertiary granite stock and dike swarm which intruded the 11 mestone (Nelson and Ross, 1969). 


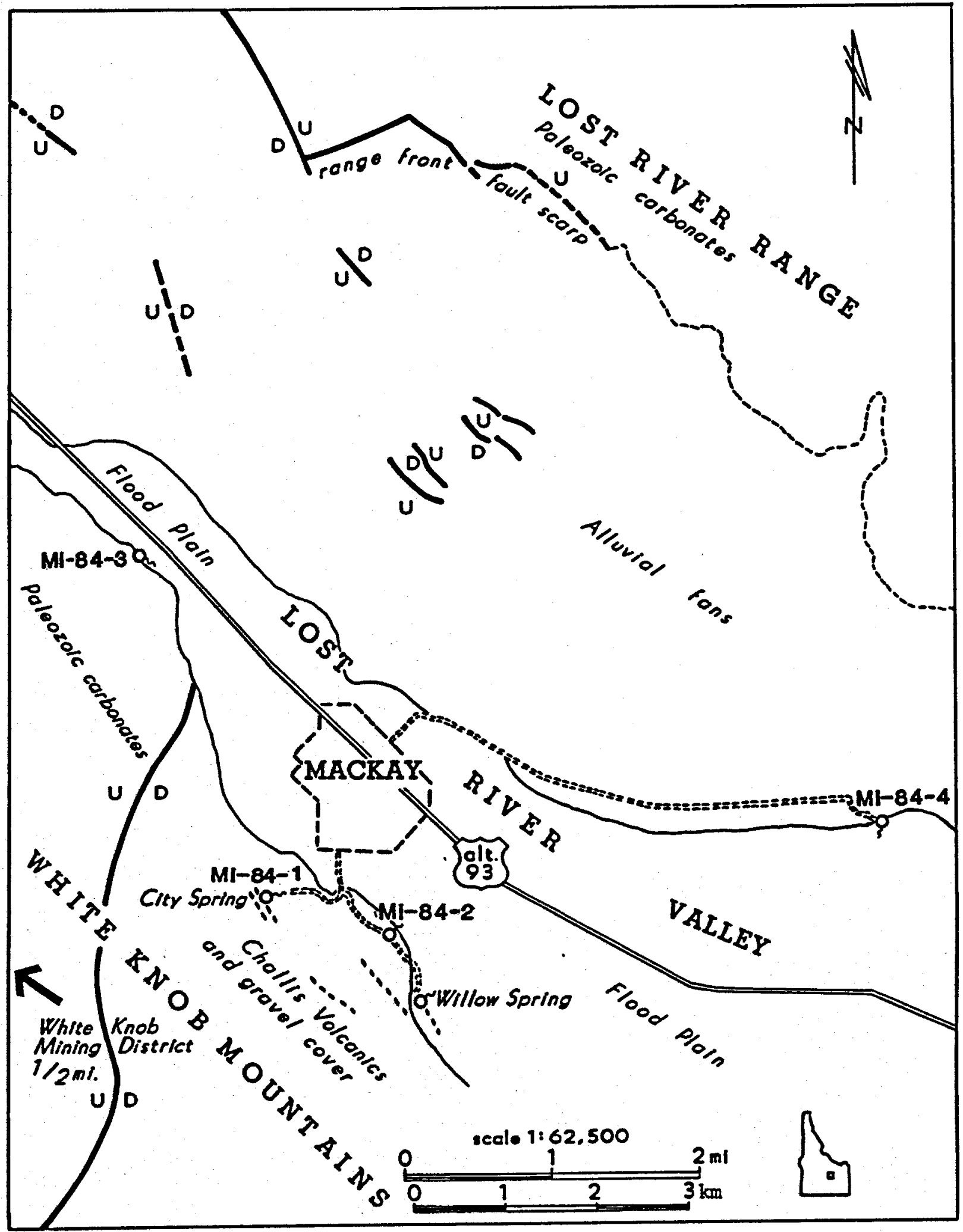

Figure 1. Sample location map and general geology of the Mackay, Idaho area. Geology generalized from Nelson and Ross (1969), with new interpretations of aerial photographs. See next page for explanation of rock units and symbols. 
EXPLANATION OF ROCK UNITS AND SYMBOLS ON FIGURE 1

Flood Plain - Quaternary alluvium.

Alluvial Fans - Quaternary sand and gravel deposits.

Challis Volcanics - Tertiary lava flows, volcanic breccias and sandstones, partially covered with Quaternary gravels (not shown).

Paleozoic Carbonates - White Knob limestone of Mississippian to Pennsylvanian age and Devonian limestone and dolomite.

Symbols:

Contact, dashed where approximate.

$U_{D} \ldots$ Fault, dashed where inferred, dotted where covered. $U$ on upthrow side and $D$ on downthrow side.

Photo-linears of probable fault origin.

4 
The Lost River Range is composed predominantly of Paleozoic carbonates. A range-front fault is clearly evident $6.5 \mathrm{~km}$ ( $4 \mathrm{miles)}$ north of Mackay, where a fault scarp is present in alluvium at the base of the mountains (Fig. 1 ). Quaternary fault scarps are also present in areas of old alluvial gravels north of the town, but have been eroded away on the younger part of the alluvial fans. Quaternary fault scarps are not evident on the hills to the south of Mackay.

Springs are common on the south side of the valley, along the foot of the White Knob Mountains. On the north side of the valley, springs are few along the alluvial fans at the base of the Lost River Range. This appears to be due to extensive and highly permeable alluvial fans on the north side of the valley which allow groundwater to flow into the valley-bottom gravels without coming to the surface. On the south side of the valley, bedrock exposures extend to the edge of the flood plain.

\section{GEOCHEMICAL SAMPLING}

City Spring issues from the head of a small draw cut in gravels in $N=1 / 4$ NE 1/4, Sec. 32, T7N, R24E (Fig. 1). Spring flow sapping appears to have formed this draw. The spring has been developed for municipal use, and is enclosed in a concrete box with a metal roof. The spring shed was locked at the time of the visit but water from a metal overflow pipe measured $18^{\circ} \mathrm{C}$ $\left(64^{\circ} \mathrm{F}\right)$. John Powers, the landowner, has dug another spring $30 \mathrm{~m}$ (100 feet) west of City Spring. The new spring, referred to as Powers' Spring, flows $22^{\circ} \mathrm{C}\left(72^{\circ} \mathrm{F}\right)$ water at about $75 \mathrm{l} / \mathrm{m}(20 \mathrm{gpm})$ from a pond $2 \mathrm{~m}$ by $4 \mathrm{~m}(6 \mathrm{ft}$ by 12 ft) wide pond dug in hematite-stained gravel. No sinter or other springrelated deposits were evident, and watercress grows abundantly in the clear water. Sample MI-84-1 (Fig. 1) was collected from Powers' Spring. City 
Spring, at the same location as Powers' Spring on Figure 1, was not sampled due to the proximity of the two springs, and the higher temperature and lesser amount of cultural disturbance at Powers' Spring. No formation bedding, geologic structures or ground alteration other than moderate hematite staining were evident around the springs. On aerial photos of the area, two short linears trending $\mathrm{N} 35^{\circ} \mathrm{W}$ are evident near City Spring.

Anderson Spring is shown on the U.S. Geological Survey Mackay, Idaho 15minute topographic map $550 \mathrm{~m}(1800 \mathrm{ft})$ southeast of City Spring. Anderson Spring was not found in this study, but an old water tank was formerly at this location and may have been mistaken for a spring.

Sample MI-84-2 (Fig. 1) was collected from a small, unmapped spring with several seeps near the road in the center of Sec. 33, T7N, R24E. The temperature of the spring was $6^{\circ} \mathrm{C}\left(43^{\circ} \mathrm{F}\right)$. It flowed about $4 \mathrm{l} / \mathrm{m}(1 \mathrm{gpm})$, and abundant snow drifts remained around the spring at the time of sampling. Snow melt, therefore, may have contributed to the low temperature. The water flows from rocks of the Challis volcanics.

Sample MI-84-3 was collected from a spring flowing about $380 \mathrm{l} / \mathrm{m}$ (100 gpm) from the base of a limestone cliff in the SE 1/4 Sec. 18, T7N, R24E. This spring has a temperature of $14^{\circ} \mathrm{C}\left(57^{\circ} \mathrm{F}\right)$. No structural control on the spring is evident on aerial photos. The water appeared to flow out of the cliff base rather than from the vertical rock face.

Sample MI-84-4 was collected from a large spring at the base of a limestone knob $5 \mathrm{~km}$ ( 3 miles) east of town, in the SE 1/4 Sec. 25, R7N, R24E (Fig. 1). Water flow from the large spring into a one-acre cattle pond was spread out over too wide an area of slow-moving water to estimate the flow rate. Water temperature was $7^{\circ} \mathrm{C}\left(45^{\circ} \mathrm{F}\right)$. The sample was collected as an example of cold groundwater from the Lost River Range recharge area on the 
north side of the valley.

Willow Spring, about one mile south of town (Fig. 1), flows about $751 / \mathrm{m}$ (20 gpm) of $10^{\circ} \mathrm{C}\left(50^{\circ} \mathrm{F}\right)$ water from coarse sand. This spring is along a northwest-trending linear which possibly represents a fault. A sample was not collected because it was felt that samples MI-84-2 and 4 would identify cold water chemistry in the area.

The few domestic wells in the Mackay area are shallow, penetrating only alluvial material, and produce cold water. Well samples can only be collected from a faucet after a surge tank system, reducing the reliability of the sample; therefore none were collected.

\section{ANALYTIC RESULTS AND INTERPRETATION OF GEOTHERMOMETRY}

Analytic results of the four water samples collected are listed in Table 1. The samples are relatively dilute, with dissolved solids contents of less than $190 \mathrm{mg} / \mathrm{l}$, and are calcium bicarbonate in nature (Fig. 2). The dilute calcium bicarbonate character of these samples suggests that they are of lowtemperature origin. Typically cation ( $\mathrm{Na}-\mathrm{K}-\mathrm{Ca})$ and silica geothermometers are used to predict the subsurface temperatures of thermal water samples (Fournier, 1981). These geothermometers, however, were developed predominantly from the chemical character of thermal waters flowing from silicate-rich terrains and are believed to be controlled by silicate-water reactions (Fournier and Rowe, 1966; Fournier and Truesde11, 1973). It is therefore likely that these geothermometers cannot be used successfully to predict subsurface temperatures for waters flowing in carbonate reservoirs. The 1 imestone recharge areas and limestone basement rocks that predominate in the Mackay area (Nelson and Ross, 1969) suggest that the waters sampled for this study have been flowing predominantly in a carbonate reservoir. 


\title{
$M I-84-1,2,3 \& 4$
}

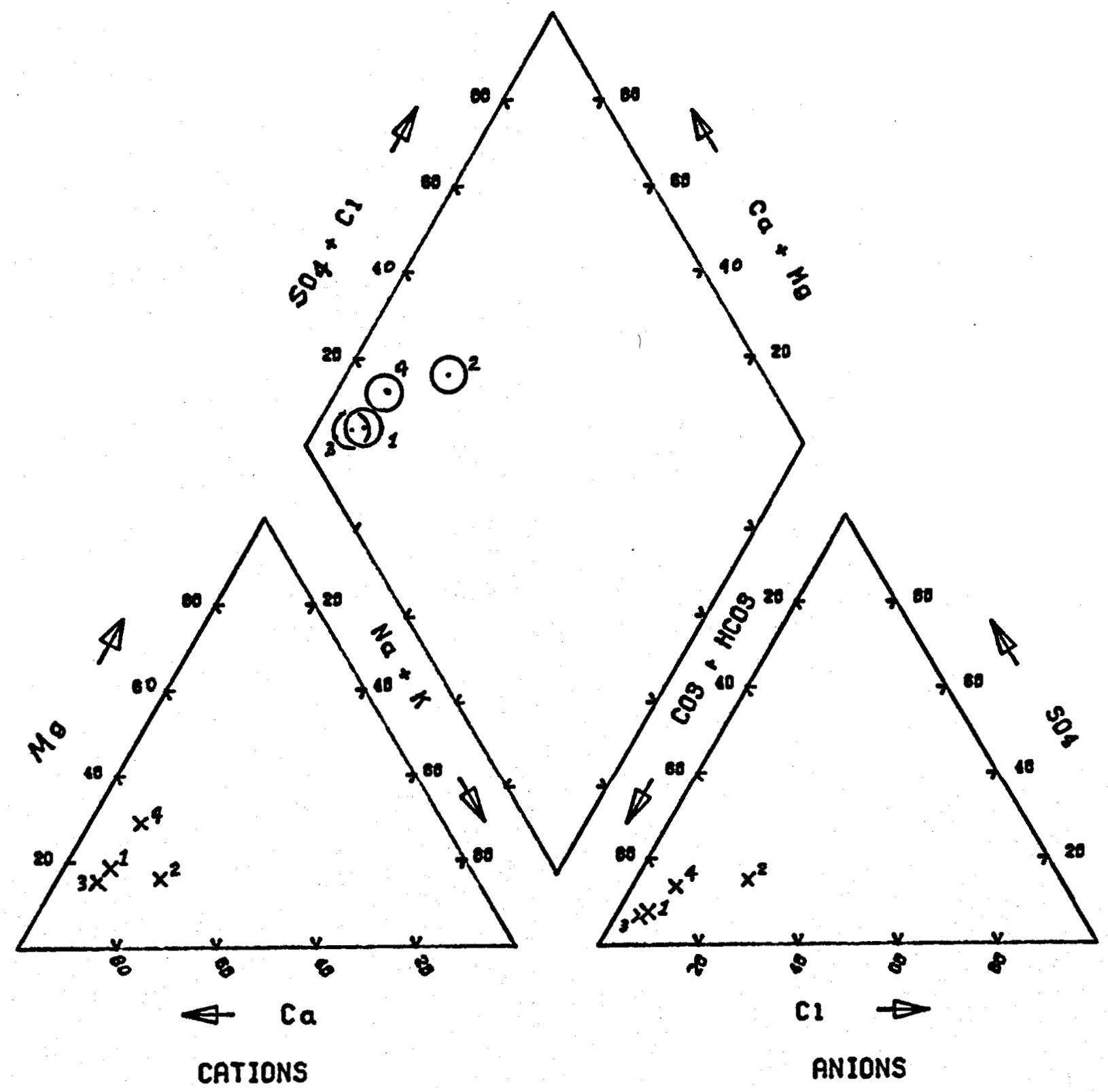

\author{
PERCENT OF TOTAL \\ MILLIEQUIVALENTS PER LITER
}

Figure 2. Piper plot of water samples from the Mackay area. 
TABLE 1

Chemistry of Spring Waters 1

Sample \# MI-84-1 MI-84-2 MI-84-3 MI-84-4

\begin{tabular}{|c|c|c|c|c|}
\hline $\mathrm{Na}$ & 6.24 & 9.62 & 5.14 & 7.31 \\
\hline$k$ & $<1.22$ & 4.90 & $<1.22$ & $<1.22$ \\
\hline $\mathrm{Ca}$ & 40.22 & 32.06 & 43.58 & 38.69 \\
\hline Zn & 0.14 & 0.31 & $<0.12$ & $<.12$ \\
\hline Mg & 6.29 & 4.78 & 5.45 & 11.32 \\
\hline $\mathrm{Sr}$ & 0.24 & 0.17 & 0.26 & 0.16 \\
\hline $\mathrm{SiO}_{2}$ & 13.27 & 54.51 & 12.29 & 6.76 \\
\hline $\mathrm{HCO}_{3}$ & 145 & 94 & 149 & 51 \\
\hline $\mathrm{SO}_{4}$ & 10 & 17 & 9 & 22 \\
\hline $\mathrm{Cl}$ & 6.0 & 20.0 & 5.0 & 9.0 \\
\hline $\mathbf{F}$ & 0.7 & 0.3 & 0.5 & 0.2 \\
\hline $\operatorname{TDS}^{2}$ & 150 & 190 & 148 & 164 \\
\hline $\mathbf{p H}$ & 7.7 & 7.4 & 7.8 & 7.9 \\
\hline Measured Temp. ${ }^{\circ} \mathrm{C}$ & 22 & 6 & 14 & 7 \\
\hline
\end{tabular}

1 Chemical analyses of $\mathrm{pH}$ and $\mathrm{HCO}_{3}$ were determined on unfiltered, untreated samples by $\mathrm{pH}$ electrode and Mohr titration, respectively. Fluoride and chloride analyses were conducted on untreated samples filtered to $0.45 \mu$ in the 1 ab by specific ion electrode and silver nitrate titration, respectively. Total dissolved solids and sulfate analyses were conducted by gravimetric methods on untreated samples filtered to $0.45 \mu$. All other elements were determined by Inductively Coupled Plasma Quantometer (ICPQ) on fluid diluted with $20 \%$ nitric acid and filtered to $0.45 \mu$ in the field. Elements analyzed for, but present at concentrations less than ICPQ 1 imits of quantitative detection (Christensen et al ., 1980), include $\mathrm{Ag}, \mathrm{As}, \mathrm{Au}$, $\mathrm{Ba}, \mathrm{Be}, \mathrm{Bi}, \mathrm{Cd}, \mathrm{Ce}, \mathrm{Co}, \mathrm{Cr}, \mathrm{Cu}, \mathrm{La}, \mathrm{Mn}, \mathrm{Mo}, \mathrm{Ni}, \mathrm{Pb}, \mathrm{Sn}, \mathrm{Sb}, \mathrm{Te}, \mathrm{Th}, \mathrm{Ti}, \mathrm{U}$, $V, W$, and $Z r$. Units in $\mathrm{mg} / 1$ ter except where otherwise noted.

2 TDS = Total dissolved solids. 
For low-temperature waters in equilibrium with carbonate rocks, such as samples MI-84-1, MI-84-3, and MI-84-4, calcite equilibrium may indicate the temperature of water-rock interaction. An approximate calculation of calcite equilibrium was therefore made using the reaction:

$$
\mathrm{CaCO}_{3}+\mathrm{H}^{+}-\mathrm{HCO}_{3}^{-}+\mathrm{Ca}^{++}
$$

The equilibrium constants for this reaction over the temperature range of $0^{\circ}$ to $350^{\circ} \mathrm{C}\left(32^{\circ}\right.$ to $\left.660^{\circ} \mathrm{F}\right)$ were taken from Helgeson (1969). Calculations of calcite equilibria in samples MI-84-1, MI-84-3, and MI-84-4 indicate that these water samples equilibrated with calcite between $0^{\circ}$ and $25^{\circ} \mathrm{C}\left(32^{\circ}\right.$ and $77^{\circ} \mathrm{F}$ ). Comparison of these calcite-equilibrium temperatures with the measured temperatures for these samples, which range from $7^{\circ}$ to $22^{\circ} \mathrm{C}\left(45^{\circ}\right.$ to $\left.72^{\circ} \mathrm{F}\right)$, suggests that these water samples are not cooled products of higher-temperature reservoir water at depth. The low reservoir temperatures of these water samples are consistent with their low dissolved-solids contents. Sample MI84-2, which has a measured temperature of only $6^{\circ} \mathrm{C}$, yields a calculated calcite equilibrium temperature of $60^{\circ} \mathrm{C}$.

Sample MI-84-2, in contrast to the other three samples, discharges from rocks of the Challis Volcanics and has had some contact with siliceous rocks, resulting in a higher $\mathrm{SiO}_{2}$ content than the other samples (Table 1). The composition of sample MI-84-2 is calcium bicarbonate in character, as are the other three, although it is slightly more enriched in $\mathrm{Na}, \mathrm{K}, \mathrm{Si}$, and $\mathrm{Cl}$. These are the elements which would be enriched by reaction with volcanic rocks. The similarities in composition suggest that this sample has a component that may have equilibrated with the carbonate-rich terrain that predominates in the Mackay area. This would, as discussed earlier, cause the calculated $\mathrm{Na}-\mathrm{K}-\mathrm{Ca}$ and $\mathrm{SiO}_{2}$ geothermometer temperatures to be suspect. The 
temperature predicted for sample MI-84-2 by the $\mathrm{Na}-\mathrm{Ca}-\mathrm{K}$ geothermometer is $43^{\circ} \mathrm{C}$. Estimated subsurface temperatures range from $-11^{\circ} \mathrm{C}$ for the low-temperature polymorph, amorphous silica, to $106^{\circ} \mathrm{C}$ for the higher-temperature polymorph, quartz. The intermediate $\mathrm{SiO}_{2}$ polymorphs of alpha-cristobalite and chalcedony predict $55^{\circ} \mathrm{C}$ and $76^{\circ} \mathrm{C}$, respectively. The low measured temperature, low dissolved solids content and the predicted temperature of less than $100^{\circ} \mathrm{C}$ for this water sample suggest that it is probably of low-temperature origin.

\section{GEOTHERMAL POTENTIAL}

The geothermometry results suggest that subsurface temperatures for the spring waters are not significantly above the measured surface temperatures. No warm springs other than Powers' and City Springs are known in the Mackay, Idaho area. The close chemical similarity between the sample from the warm springs (MI-84-1) and the cold-water springs suggests that all the springs consist of normal groundwater. Sample MI-84-2 contains slightly more dissolved silica than the other samples because the spring issues from rocks of the Challis Volcanics. Its low measured temperature and general chemical similarity to the other samples suggest that it is also normal groundwater. The slightly higher than background temperature of Powers Spring is probably due to the water circulating to moderate depth along the normal faults in the area. The Lost River Range to the northeast of Mackay and the White Knob Mountains to the south are probably the principal recharge areas for groundwater. Groundwater recharge from the Lost River Range and the White Knob Mountains circulates to depth along range front faults and possibly within permeable limestone beds. The potential for finding a shallow geothermal resource with a temperature significantly above $22^{\circ} \mathrm{C}$ appears to be very low in the Mackay area. 


\section{ACKNOWLEDGEMENTS}

This study was funded by the Department of Energy under Contract No. DEAC07-80ID12079 as part of the State Coupled geothermal program. We thank John Powers for serving as field guide during the sample collection. 


\section{REFERENCES CITED}

Christensen, 0. D., Kroneman, R. L., and Capuano, R. M., 1980, Multielement analysis of geologic materials by inductively coupled plasma--atomic emission spectroscopy: Earth Science Laboratory, University of Utah Research Institute Report ESL-32, DOE/ID/12079-2.

Fournier, R. 0., 1981, Application of water geochemistry to geothermal exploration and reservoir engineering; Chapt. 4 in Geothermal Systems: Principles and Case Histories: L. Ryback and L. J. P. Muffler, eds., Wiley, New York, p. 109-143.

Fournier, R. 0., and Rowe, J. J., 1966, Estimation of underground temperatures from the silica content of water from hot springs and wet-steam wells: Am. J. Sci., v. 264, P. 685-697.

Fournier, R. O., and Truesdell, A. H., 1973, An empirical Na-K-Ca geothermometer for natural waters: Geochim. Cosmochim. Acta, v. 37, P. 1255-1275.

Helgeson, H. C., 1969, Thermodynamics of hydrothermal systems at elevated temperatures and pressures: Am. J. Sci., v. 267, p. 729-804.

Nelson, H. H., and Ross, C. P., 1969, Geologic map of the Mackay quadrangle south-central Idaho: U.S. Geol. Survey, Mis. Geol. Invest., Map I-580. 